\title{
Pengaruh Temperatur dan Media Pendingin pada Proses Heat Treatment Baja AISI 1045 terhadap Kekerasan dan Laju Korosi
}

\author{
Eko Nugroho ${ }^{1}$, Sulis Dri Handono², Asroni ${ }^{3}$, Wahidin ${ }^{4}$ \\ Jurusan Teknik Mesin, Fakultas Teknik, Universitas Muhammadiyah Metro \\ Jl. Ki Hajar Dewantara 15 A Kota Metro, Lampung, Indonesia \\ Email: exonugros@yahoo.co.id'1 , esdehaa@gmail.com², as.roni@aol.com³, \\ wahidin123@yahoo.com
}

\begin{abstract}
Abstrak
Baja karbon adalah logam yang paling banyak digunakan pada dunia industri dan untuk memenuhi kebutuhan hidup manusia. Salah satu jenis baja yang paling banyak digunakan adalah baja AISI 1045 atau baja karbon sedang. Baja AISI 1045 dibuat dan dibentuk komponen, sparepart, atau alat-alat sesuai dengan kebutuhan di dunia industri, maka muncul upaya untuk memperbaiki sifat mekanik dan ketahanan terhadap korosi. Tujuan dari penelitian ini adalah untuk mengetahui pengaruh temperatur dan media pendingin pada proses heat treatment terhadap nilai kekerasan baja AISI 1045, mengetahui pengaruh temperatur dan media pendingin pada proses heat treatment terhadap laju korosi baja AISI 1045. Pada penelitian ini spesimen dipanaskan menggunakan tungku pemanas dengan temperatur $750^{\circ} \mathrm{C}, 850^{\circ} \mathrm{C}$, dan $950^{\circ} \mathrm{C}$ dengan holding time selama 30 menit. Kemudian masing-masing material dilakukan quenching pada media air mineral dan oli SAE 10w-40. Selanjutnya material dilakukan uji kekerasan dan uji korosi. Hasilnya material mengalami perubahan kekerasan dan laju korosi. Nilai kekerasan tertinggi terjadi pada media pendingin air mineral yaitu 58,2 HRC pada variasi temperatur $850^{\circ} \mathrm{C}$ dan nilai kekerasan tertinggi media pendingin oli adalah 33,4 HRC pada variasi temperatur $950^{\circ} \mathrm{C}$. Laju korosi tertinggi media pendingin air mineral adalah 3,998 ipy pada variasi temperatur $950^{\circ} \mathrm{C}$, dan 4,086 ipy pada media pendingin oli dengan variasi temperatur $950^{\circ} \mathrm{C}$.
\end{abstract}

Kata kunci: Temperatur, media pendingin, heat treatment, kekerasan, dan laju korosi.

\section{Pendahuluan}

Perkembangan dunia industri semakin hari semakin pesat terutama industri otomotif, dimana banyak persusahaan baru muncul begitu pula dengan perusahaan yang sudah ada merekapun terus mengembangkan perusahaanya. Semakin berkembangnya industri otomotif di indonesia dikarenakan terus bertambahnya kebutuhan akan transportasi. Pada tahun 2017 menurut data Asosiasi Industri Sepeda Motor Indonesia (AISI) sekitar 5.888.103 unit sepeda motor terjual di indonesia belum yang termasuk eksport, dan sekitar 500.000 lebih mobil terjual [1]. Semakin banyak kendaraan yang terjual maka kebutuhan akan material juga semakin bertambah. Baja AISI 1045 adalah jenis material yang banyak digunakan dalam dunia industri otomotif. Baja AISI 1045 digolongkan dalam jenis material baja karbon sedang, dimana biasanya jenis material banyak digunakan untuk membuat berbagai macam komponen dan sparepart mesin yang berkekuatan sedang seperti poros roda, gear, rantai, kruk as, dan masih banyak yang lainnya. Dimana komponen mesin seperti poros roda, gear, dan rantai adalah komponen mesin yang jarang mendapat pelapisan atau juga pelumasan sehingga rawan terjadi korosi. Baja AISI 1045 memiliki kandungan karbon antara $0,43 \%-0,5 \%$. Mampu mesin dari baja AISI 1045 ini sangat baik, sehingga dapat dimesin oleh berbagai jenis mesin perkakas. Akan tetapi untuk mendapatkan sifat material yang diinginkan maka perlu dilakukan perlakuan panas (heat treatment). 
Proses perlakuan panas secara umum terdiri dari proses hardening, tempering, carburizing dan annealing. Faktor yang mempengaruhi kekerasan heat treatment adalah temperatur, holding time (waktu penahanan) dan media pendingin. Pada penelitian ini fokus pada hardening khususnya pada penggunaan media pendingin proses quenching. Quenching (celup cepat) adalah salah satu perlakuan panas dengan laju pendinginan cepat yang dilakukan dalam suatu media pendingin misal air atau oli untuk memperoleh sifat mekanik yang lebih keras [2].

Temperatur pada perlakuan panas sangat berpengaruh terhadap nilai kekerasan ataupun laju korosi material tersebut, karena saat baja dipanaskan sampai titik temperatur austenit kemudian didinginkan secara mendadak/quenching dengan kecepatan pindinginan di atas kecepatan pendinginan kritis agar terjadi pembentukan martensit dan diperoleh kekerasan yang tinggi. Media pendingin yang digunakan berpengaruh terhadap laju pendinginan dalam terbentuknya struktur martensite hasil transformasi austenite. Martensite inilah yang akan menentukan seberapa jauh peningkatan sifat mekanis hasil perlakuan panas. Media pendingin selain mempengaruhi sifat mekanis dapat mempengaruhi sifat fisis. Dari proses quenching spesimen sering sekali mengalami cracking, distorsi, dan ketidakseragaman kekerasan yang diakibatkan oleh tidak seragamnya temperatur larutan pendingin [3]. Selain mempengaruhi sifat fisis dan mekanis perlakuan panas juga mempengaruhi terhadap laju korosi, dimana semakin tinggi temperatur yang diberikan maka akan besar juga laju korosinya. Perlakuan panas pada baja akan mempengaruhi pada korosi sebagai akibat adanya pengendapan fasa lain atau peningkatan dan penurunan tegangan, suatu endapan dapat bersifat anodik atau katodik terhadap matriks logamnya, dengan perlakuan panas bila timbul endapan akan terbentuk anoda dan katoda yang menyebabkan timbulnya korosi [4].

Pada penelitian sebelumnya Perdana, pada 2017 [5] untuk mengetahui seberapa besar pengaruh temperatur terhadap laju korosi dilakukan penelitian dengan variasi temperatur yaitu sebesar $600,700,800$, dan $900^{\circ} \mathrm{C}$, sedangkan holding time dan media pendingin pada proses quenching tidak dilakukan variasi yaitu untuk holding time 30 menit, dan media pendingin menggunakan air biasa. Dimana hasil yang didapatkan adalah temperatur $600^{\circ} \mathrm{C}$ laju korosinya adalah 11.2208931 mpy dan memiliki selisih berat $80 \mathrm{mg}$ dari berat awal, temperatur $700^{\circ} \mathrm{C}$ laju korosinya 12.6235047 mpy dan memiliki selisih berat $90 \mathrm{mg}$, temperatur $800^{\circ} \mathrm{C}$ laju korosinya $21.0391745 \mathrm{mpy}$ dan selisih berat $150 \mathrm{mg}$, temperatur $900^{\circ} \mathrm{C}$ laju korosinya 30.8574559 mpy dan memiliki selisih berat $220 \mathrm{mg}$.

Pada penelitian ini penulis memvariasikan temperatur dan media pendingin. Media pendingin yang digunakan salah satunya adalah oli, dimana oli sendiri memiliki kekentalan yang cukup kental dibandingkan air biasa sehingga penurunan panas pada saat quenching tidak terlalu cepat dan menghasilkan material yang tidak terlalu keras.

\section{Tinjauan Pustaka}

\section{Baja karbon}

Baja karbon merupakan salah satu jenis baja paduan yang terdiri atas unsur besi (Fe) dan karbon (C). Dimana besi merupakan unsur dasar dan karbon sebagai unsur paduan utamanya. Dalam proses pembuatan baja akan ditemukan pula penambahan kandungan unsur kimia lain seperti sulfur (S), fosfor $(\mathrm{P})$, slikon ( $\mathrm{Si})$, mangan (Mn) dan unsur kimia lainnya sesuai dengan sifat baja yang diinginkan. Baja karbon memiliki kandungan unsur karbon dalam besi sebesar 0,2 \% hingga $2,14 \%$, dimana kandungan karbon tersebut berfungsi sebagai unsur pengeras dalam struktur baja. 
Dalam pengaplikasiannya baja karbon sering digunakan sebagai bahan baku untuk pembuatan alat-alat perkakas, komponen mesin, struktur bangunan, dan lain sebagainya. Menurut pendefenisian ASM handbook vol.1:148 (1993) [6], baja karbon dapat diklasifikasikan berdasarkan jumlah persentase komposisi kimia karbon dalam baja yakni sebagai berikut :

1. Baja Karbon Rendah (Low Carbon Steel)

Baja karbon rendah merupakan baja dengan kandungan unsur karbon dalam sturktur baja kurang dari $0,3 \%$ C. Baja karbon rendah ini memiliki ketangguhan dan keuletan tinggi akan tetapi memiliki sifat kekerasan dan ketahanan aus yang rendah. Pada umumnya baja jenis ini digunakan sebagai bahan baku untuk pembuatan komponen struktur bangunan, pipa gedung, jembatan, bodi mobil, dan lain-lainya.

2. Baja Karbon Sedang (Medium Carbon Steel)

Baja karbon sedang merupakan baja karbon dengan persentase kandungan karbon pada besi sebesar $0,3 \% \mathrm{C}-0,59 \%$ C. Baja karbon ini memiliki kelebihan bila dibandingkan dengan baja karbon rendah, baja karbon sedang memiliki sifat mekanis yang lebih kuat dengan tingkat kekerasan yang lebih tinggi dari pada baja karbon rendah. Besarnya kandungan karbon yang terdapat dalam besi memungkinkan baja untuk dapat dikeraskan dengan memberikan perlakuan panas (heat treatment) yang sesuai. Baja karbon sedang biasanya digunakan untuk pembuatan poros, rel kereta api, roda gigi, baut, gear, pegas, dan komponen mesin lainnya.

3. Baja Karbon Tinggi (High Carbon Steel)

Baja karbon tinggi adalah baja karbon yang memiliki kandungan karbon sebesar $0,6 \% \mathrm{C}-1,4 \% \mathrm{C}$. Baja karbon tinggi memiliki sifat tahan panas, kekerasan serta kekuatan tarik yang sangat tinggi akan tetapi memiliki keuletan yang lebih rendah sehingga baja karbon ini menjadi lebih getas. Baja karbon tinggi ini sulit diberi perlakuan panas untuk meningkatkan sifat kekerasannya, hal ini dikarenakan baja karbon tinggi memiliki jumlah martensit yang cukup tinggi sehingga tidak akan memberikan hasil yang optimal pada saat dilakukan proses pengerasan permukaan. Dalam pengaplikasiannya baja karbon tinggi banyak digunakan dalam pembuatan alat-alat perkakas seperti palu, gergaji, pembuatan kikir, pisau cukur, dan sebagainya.

\section{Diagram fasa besi karbon (Fe-C)}

Diagram fasa $\mathrm{Fe}-\mathrm{C}$ atau biasa disebut diagram kesetimbangan besi karbon merupakan diagram yang menjadi parameter untuk mengetahui segala jenis fasa yang terjadi di dalam baja, serta untuk mengetahui faktor-faktor apa saja yang terjadi pada paduan baja dengan segala perlakuannya.

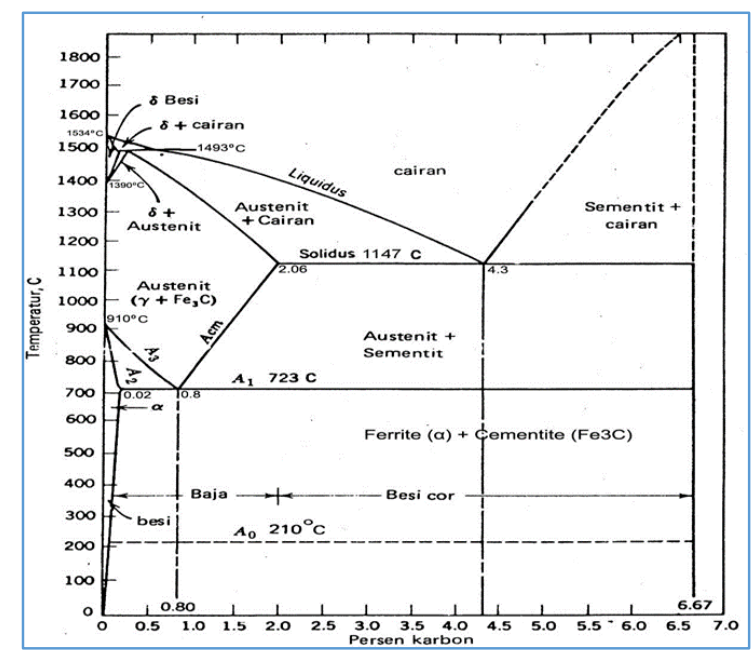

Gambar 1. Diagram kesetimbangan FE-C

Dari diagram fasa terlihat bahwa temperatur sekitar $723^{\circ} \mathrm{C}$ merupakan temperatur transformasi austenit menjadi fasa perlit (yang merupakan gabungan fasa ferit dan sementit). Transformasi fasa ini dikenal sebagai reaksi eutectoid dan merupakan dasar proses perlakuan panas dari baja. Sedangkan daerah fasa yang prosentase larutan karbon hingga $2 \%$ yang terjadi di temperatur $1.147^{\circ} \mathrm{C}$ merupakan daerah besi gamma $(\gamma)$ atau disebut austenit. Pada kondisi ini biasanya austenit bersifat stabil, lunak, ulet, mudah dibentuk, 
tidak ferro magnetis dan memiliki struktur kristal Face Centered Cubic (FCC).

Besi murni pada temperatur di bawah $910^{\circ} \mathrm{C}$ mempunyai struktur kristal Body Centered Cubic (BCC). Besi BCC dapat melarutkan karbon dalam jumlah sangat rendah, yaitu sekitar $0,02 \%$ maksimum pada temperatur $723^{\circ} \mathrm{C}$. Larutan pada intensitas dari karbon di dalam besi ini disebut juga besi alpha $(\alpha)$ atau fasa ferit. Pada temperatur diantara $910^{\circ} \mathrm{C}$ sampai $1.390^{\circ} \mathrm{C}$, atom-atom besi menyusun diri menjadi bentuk kristal Face Centred Cubic (FCC) yang juga disebut besi gamma $(\gamma)$ atau fasa austenit. Besi gamma ini dapat melarutkan karbon dalam jumlah besar yaitu sekitar 2,06 \% maksimum pada temperatur sekitar $1.147^{\circ} \mathrm{C}$. Penambahan karbon ke dalam besi FCC ditransformasikan kedalam struktur $\mathrm{BCC}$ dari $910^{\circ} \mathrm{C}$ menjadi $723^{\circ} \mathrm{C}$ pada kadar karbon sekitar 0,8\%. Diantara temperatur $1.390^{\circ} \mathrm{C}$ dan temperatur cair $1.534^{\circ} \mathrm{C}$, besi gamma berubah menjadi susunan $\mathrm{BCC}$ yang disebut besi delta $(\delta)$.

Ada beberapa hal yang perlu diperhatikan didalam diagram $\mathrm{Fe}-\mathrm{Fe} 3 \mathrm{C}$ yaitu, perubahan fasa ferit atau besi alpha $(\alpha)$, austenit atau besi gamma $(\gamma)$, sementit atau karbida besi, perlit, dan sementit.

\section{Diagram TTT (Time Temperature Transformation)}

Untuk mendapatkan sifat-sifat bahan yang lebih baik sesuai dengan karakter yang diinginkan dapat dilakukan melalui pemanasan dan pendinginan. Tujuannya adalah mengubah struktur mikro sehingga bahan dikeraskan, dimudakan atau dilunakan.

Pemanasan bahan dilakukan diatas garis transformasi kira-kira pada $770 \mathrm{oC}$, sehingga perlit berubah menjadi austenit yang homogen karena terdapat cukup karbon. Pada temperatur yang lebih tinggi ferrit menjadi austenit karena atom karbon difusi ke dalam ferrit tersebut. Untuk pengerasan baja, pendinginan dilakukan dengan cepat melalui pencelupan kedalam air, minyak atau bahan pendingin lainnya sehingga atom-atom karbon yang telah larut dalam austenit tidak sempat membentuk sementit dan ferrit akibatnya austenit menjadi sangat keras yang disebut martensit.

Pada baja setelah terjadi austenit dan ferrit kadar karbonya akan menjadi makin tinggi sesuai dengan penurunan temperatur dan akan membentuk hipoeutektoid. Pada saat pemanasan maupun pendinginan difusi atom karbon memerlukan waktu yang cukup. Laju difusi pada saat pemanasan ditentukan oleh unsur-unsur paduanya dan pada saat pendinginan cepat austenit yang berbutir kasar akan mempunyai banyak martensit.

Fase kristal dan besarnya butir yang terjadi akan membentuk sifat baja. Apabila ferrit dan sementit di dalam perlit berbutir besar, maka baja tersebut makin lunak sebagai akibat pendinginan lambat. Sebaliknya baja menjadi semakin keras apabila memiliki perlit berbutir halus yang diperoleh pada pendinginan cepat. Baja dengan unsur paduan aluminium, vanadium, titanium, dan zirkonim akan cenderung memiliki kristal berbutir halus. Untuk memahami macam-macam fase dan struktur kristal yang terjadi pada saat pendinginan dapat diamati dari diagram TTT.

Fasa austenit stabil berada di atas temperatur $770^{\circ} \mathrm{C}$ Pada temperatur yang lebih rendah akan terbentuk martensit dan mulai temperatur tersebut martensit sudah tidak tergantung pada kecepatan pendinginan. Struktur bainit akan terbentuk setelah terbentuknya ferrit dan sementit. Jadi campuran antara ferrit dan sementit adalah bainit seperti pada perlit. Perbedaan antara bainit dengan perlit adalah bentuknya halus sedangkan perlit kasar.

Diagram TTT dipengaruhi oleh kadar karbon dalam baja, makin besar kadar karbonya maka diagramnya akan semakin bergeser ke kanan, demikian pula dengan unsure paduan lainnya. Apabila baja dipanaskan sampai terbentuknya austenit, pendinginan akan berlangsung terus 
menerus tidak isothermal biarpun dilakukan dengan berbagai media pendingin.

Untuk menentukan laju reaksi perubahan fasa yang terjadi dapat diperoleh dari diagram TTT (Time Temperature Transformation). Diagram TTT untuk baja karbon dengan $\mathrm{C}$ kurang dari 0,8\% (hipoeutectoid) ditunjukkan dalam gambar 2. Sedangkan diagram TTT untuk baja $\mathrm{C}$ sama dengan $0,8 \%$ (eutectoid) diberikan dalam gambar 3 .

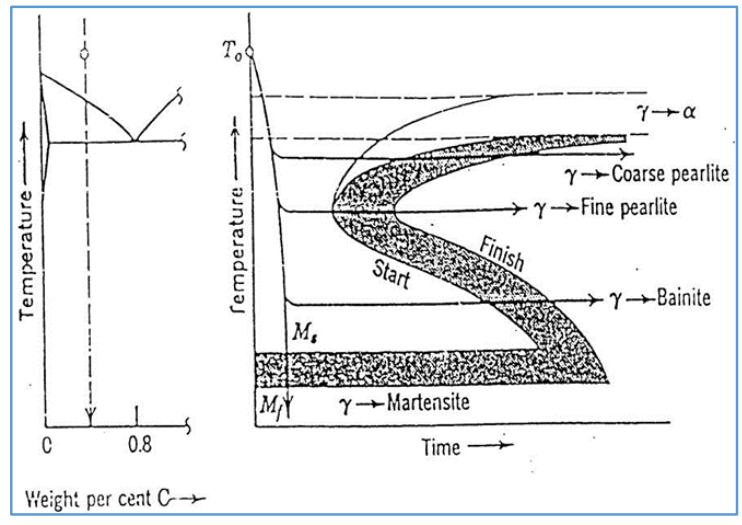

Gambar 2. Diagram TTT untuk baja Hipoeutectoid $(\mathrm{C}<0,8 \%)$

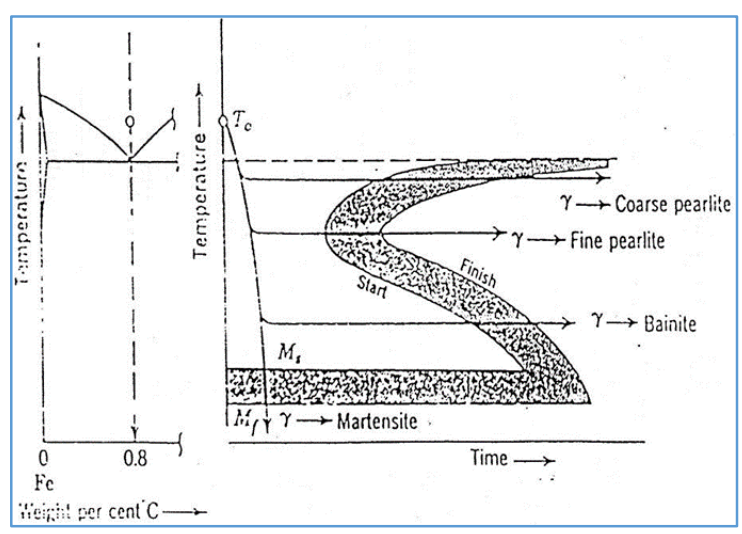

Gambar 3. Diagram TTT untuk baja eutectoid $(\mathrm{C}=0,8 \%)$

Dari diagram TTT menunjukkan bentuk hidung (nose) sebagai batasan waktu minimum dimana sebelum waktu tersebut bertransformasi austenit ke perlit tidak akan terjadi. Posisi hidung dari diagram TTT dapat bergeser menurut kadar karbon. Posisi hidung bergeser makin kekanan yang berarti baja karbon itu makin mudah untuk membentuk bainit/martensit atau makin mudah untuk dikeraskan. Sedangkan Ms merupakan temperatur awal mulai terbentuknya fasa martensit dan Mf merupakan temperatur akhir dimana martensit masih bisa terbentuk.

Untuk mendapatkan hubungan antara kecepatan pendinginan dan struktur mikro yang terbentuk biasanya dilakukan dengan menggabungkan diagram kecepatan pendinginan kedalam diagram TTT yang dikenal dengan diagram CCT (Continous Cooling Transformation) seperti yang terlihat dalam gambar 4.

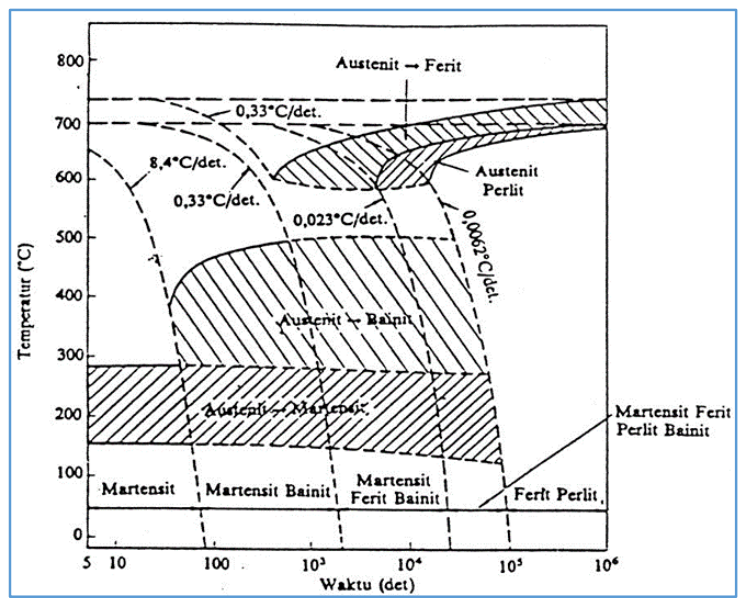

Gambar 4. Diagram CCT (Continous Cooling Transformation)

Pada contoh gambar diagram CCT menjelaskan bahwa bila kecepatan pendinginan naik berarti bahwa waktu pendinginan dari temperatur austenit turun, struktur akhir yang terjadi berubah dari campuran ferit-perlit ke campuran feritperlit-bainit-martensit, ferit-bainitmartensit, kemudian bainit- martensit dan akhirnya pada kecepatan yang tinggi sekali struktur yang terjadi adalah martensit.

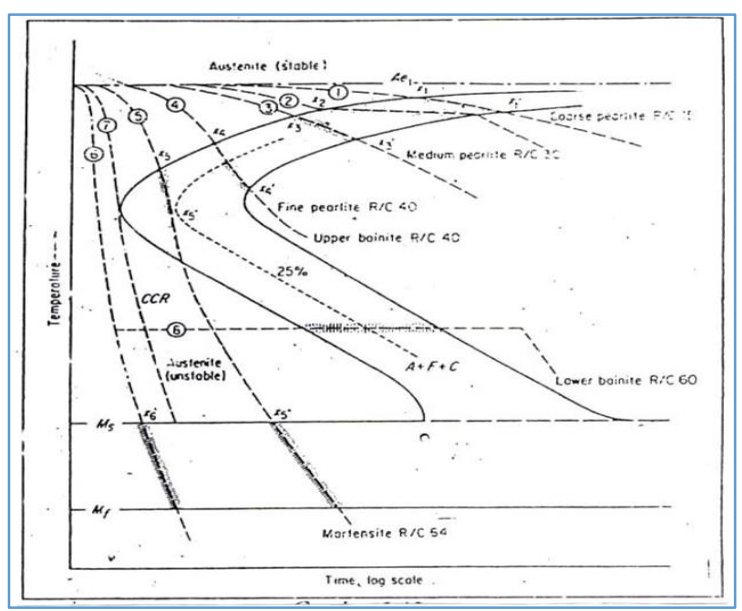

Gambar 5. Kurva Pendinginan pada Diagram TTT 
Dari diagram pendinginan dapat dilihat bahwa dengan pendinginan cepat (kurva 6) akan menghasilkan struktur martensite karena garis pendinginan lebih cepat daripada kurva 7 yang merupakan laju pendinginan kritis (critical cooling rate) yang nantinya akan tetap terbentuk fase austenite (unstable). Sedangkan pada kurva 6 lebih cepat daripada kurva 7, sehingga terbentuk struktur martensite yang keras, tetapi bersifat rapuh karena tegangan dalam yang besar.

Jadi dapat disimpulkan bahwa dengan proses heat treatment pada baja karbon akan meningkatkan kekerasanya. Dengan meningkatnya kekerasan, maka efeknya terhadap kekuatan adalah sebagai berikut :

1) Kekuatan impact (impact strength) akan turun karena dengan meningkatnya kekerasan, maka tegangan dalamnya akan meningkat. Karena pada pengujian impak beban yang bekerja adalah beban geser dalam satu arah, maka tegangan dalam akan mengurangi kekuatan impak.

2) Kekuatan tarik (tensile strength) akan meningkat. Hal ini disebabkan karena pada pengujian tarik beban yang bekerja adalah secara aksial yang berlawanan dengan arah dari tegangan dalam, sehingga dengan naiknya kekerasan akan meningkatkan kekuatan tarik dari suatu material.

\section{Metode Penelitian}

\section{Variabel penelitian}

a) Variabel bebas: variasi temperatur pemanasan $750^{\circ} \mathrm{C}, 850^{\circ} \mathrm{C}$, dan $950^{\circ} \mathrm{C}$ serta jenis media quenching air mineral dan oli SAE 10w-40.

b) Variabel terikat yang diamati dalam penelitian ini adalah kekrasan dan laju korosi.

c) Variabel terkontrol : baja AISI 1045 dan holding time 30 menit.

\section{Waktu dan tempat penelitian}

Penelitan dilakukan pada bulan Agustus 2018. Penelitian ini dilakukan di
Tempuran 12c dan Laboratorium Teknik Mesin Kampus 2 Fakultas Teknik Universitas Muhammadiyah Metro.

\section{Prosedur penelitian}

Prosedur penelitian memiliki beberapa langkah diantaranya adalah langkah pembuatan bahan uji, langkah pengujian, dan instrumen pengambilan data serta analisa data.

Langkah Pembuatan Bahan Uji

1. Mempersiapkan alat dan bahan,

2. Material kemudian dibubut supaya mendapatkan spesimen yang ukuran diameter dan panjangnya sama,

3. Kemudian potong spesimen sesuai dengan ukuran diameter $40 \mathrm{~mm}$ dan lebar $30 \mathrm{~mm}$ sebanyak 21 buah,

4. Amplas permukaan spesimen yang sudah dipotong tadi sampai permukaanya rata, bebas dari kotoran maupun karat dengan ukuran amplas 240, 500, 100, kemudian 1500.

Langkah Pengujian

1. Mempersiapkan semua bahan yang akan digunakan dalam melakukan pengujian,

2. Menyiapkan spesimen,

3. Masukan spesimen pada tungku pemanas dengan temperatur: $750^{\circ} \mathrm{C}$ sebanyak 6 buah. $850^{\circ} \mathrm{C}$ sebanyak 6 buah $950^{\circ} \mathrm{C}$ sebanyak 6 buah, holding time 30 menit,

4. Quenching spesimen pada air dan oli dengan volume yang sama yaitu 2 liter dengan jumlah spesimen : Temperatur $750^{\circ} \mathrm{C}$, oli 3 buah dan air 3 buah. Temperatur $850^{\circ} \mathrm{C}$, oli 3 buah dan air 3 buah. Temperatur $950^{\circ} \mathrm{C}$, oli 3 buah dan air 3 buah,

5. Uji kekerasan dengan alat uji Rockwell sebanyak 5 titik pada setiap spesimen,

6. Timbang berat awal spesimen,

7. Rendam spesimen pada cairan asam $\mathrm{H} 2 \mathrm{SO} 4$ selama 22 jam,

8. Timbang berat akhir spesimen. 


\section{Hasil dan Pembahasan}

\section{Hasil pengujian rockwell}

Pada penelitian ini uji kekerasan menggunakan Rockwell model HR-150A dengan nilai Hardness Rockwell C . Tujuan dari pengujian ini adalah supaya dapat mengetahui perubahan nilai kekerasan dari setiap spesimen yang diberikan heat treatmnet. Dari penelitian didapatkan nilai rata-rata kekerasan raw material adalah 11,4 HRC. Pengujian pada raw material ini dilakukan sebagai bahan perbandingan dengan material yang telah diberikan heat treatment nantinya.

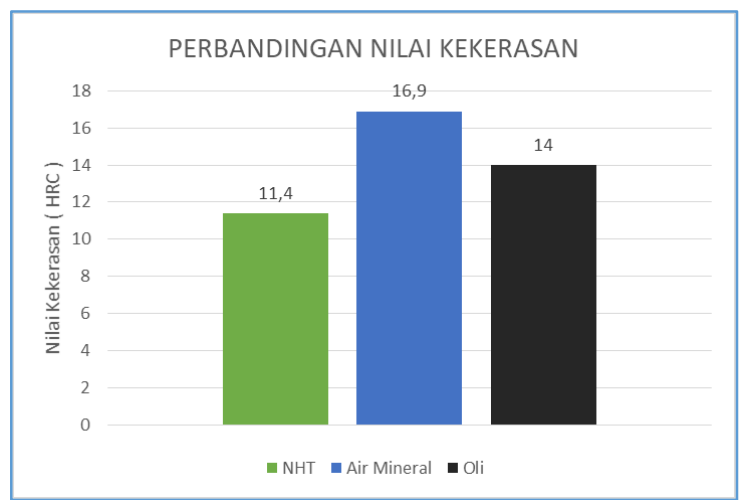

Gambar 6. Perbandingan nilai kekerasan dengan temperatur $750^{\circ} \mathrm{C}$

Pada grafik di atas menunjukkan nilai kekerasan material setelah mendapatkan heat treatment kemudian di quenching dengan media pendingin air adalah 16,9 HRC dan media pendingin oli 14 HRC. Sedangkan raw material/non heat treatment sebesar 11,4 HRC. Material yang diberikan heat treatment mengalami peningkatan nilai kekerasan dari material yang tidak diberikan heat treatment, dan material yang didinginkan dengan air memiliki nilai kekerasan tertinggi. Pada grafik gambar 7 menunjukkan nilai kekerasan material setelah mendapatkan heat treatment kemudian di-quenching dengan media pendingin air adalah 58,2 HRC dan media pendingin oli 33 HRC. Material yang diberikan heat treatment mengalami peningkatan nilai kekerasan yang sangat signifikan dari material yang tidak diberikan heat treatment, dan material yang didinginkan dengan air mengalami peningkatan kekerasan lebih dari 5 kali lipat dari material non heat treatment.

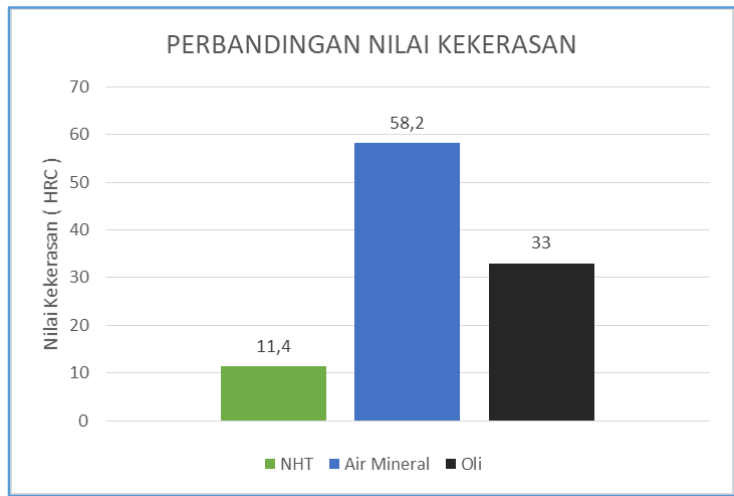

Gambar 7. Perbandingan nilai kekerasan dengan temperatur $850^{\circ} \mathrm{C}$

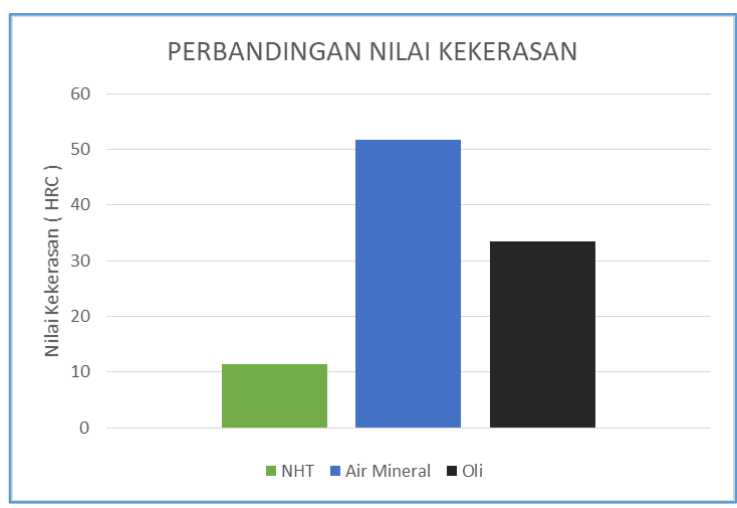

Gambar 8. Perbandingan nilai kekerasan dengan temperatur $950^{\circ} \mathrm{C}$

Nilai kekerasan material setelah mendapatkan heat treatment kemudian diquenching dengan media pendingin air adalah 51,7 HRC dan media pendingin oli 33,4 HRC. Material yang diberikan heat treatment mengalami peningkatan nilai kekerasan yang signifikan dari material yang tidak diberikan heat treatment, dan material yang didinginkan dengan air mengalami peningkatan kekerasan lebih tinggi dibandingkan material yang didinginkan dengan oli.

\section{Pengaruh nilai temperatur terhadap nilai kekerasan material dengan media pendingin air mineral}

Nilai kekerasan meningkat ketika material mendapatkan heat treatment dari mulai temperatur $750^{\circ} \mathrm{C}$ sampai temperatur $850^{\circ} \mathrm{C}$ (Gambar 9). Dimana nilai kekerasan raw material adalah 11,4 HRC meningkat menjadi $16,9 \mathrm{HRC}$ di temperatur $750^{\circ} \mathrm{C}$ dan 
kemudian meningkat sangat signifikan di temperatur $850^{\circ} \mathrm{C}$ menjadi $58,2 \mathrm{HRC}$ dan cenderung menurun menjadi 51,7 $\mathrm{HRC}$ di temperatur $950^{\circ} \mathrm{C}$.

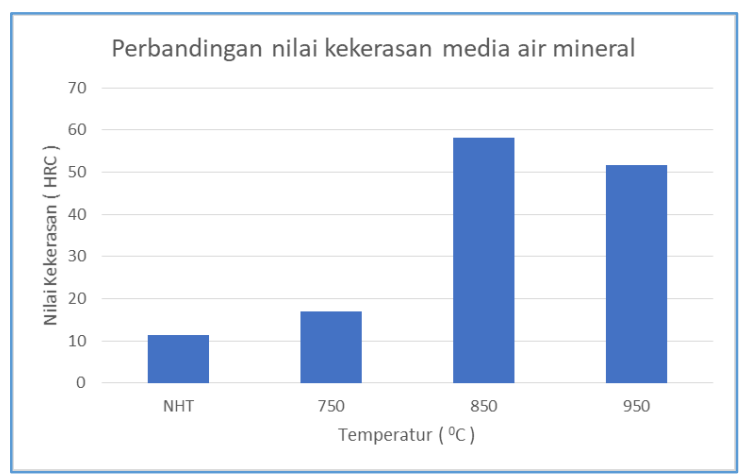

Gambar 9. Pengaruh temperatur heat treatment terhadap nilai kekerasan media pendingin air mineral

Hal demikian ini diakibatkan semakin tinggi temperatur hardening pada proses quenching, semakin menurun pula nilai kekerasan yang dihasilkan, dikarenakan apabila baja karbon sedang $(0,44 \% \mathrm{C})$ dipanaskan melebihi temperatur $850^{\circ} \mathrm{C}$ pada saat proses hardening, karbida yang terlarut semakin banyak dan membentuk butiran austenit yang relatif semakin besar [7].

\section{Pengaruh nilai temperatur terhadap nilai kekerasan material dengan media pendingin oli}

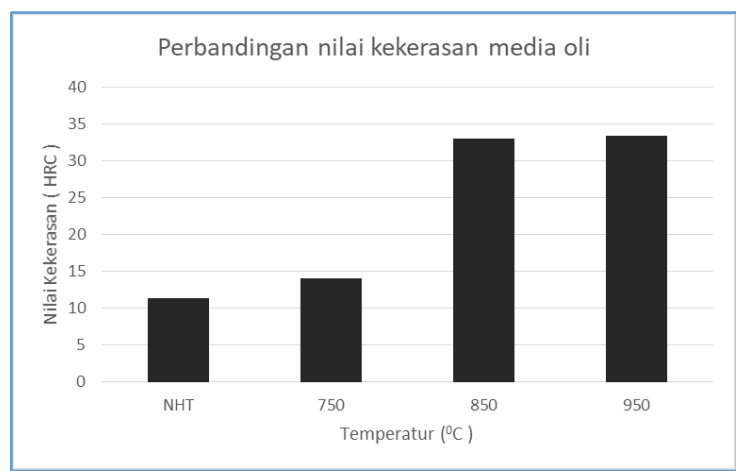

Gambar 10. Pengaruh temperatur heat treatment terhadap nilai kekerasan media pendingin oli

Dari data pada gambar 10, media pendingin oli mengalami kenaikan nilai kekerasan dari raw material sampai dengan temperatur $950^{\circ} \mathrm{C}$ dan tidak terlalu signifikan akan tetapi tidak juga mengalami penurunan nilai kekerasan seperti pada media pendingin air mineral. Hal ini diakarenakan oli memiliki sifat mendinginkan teratur sehingga martensite yang terbentuk lebih sedikit.

\section{Perbandingan media pendingin terhadap nilai kekerasan tertinggi}

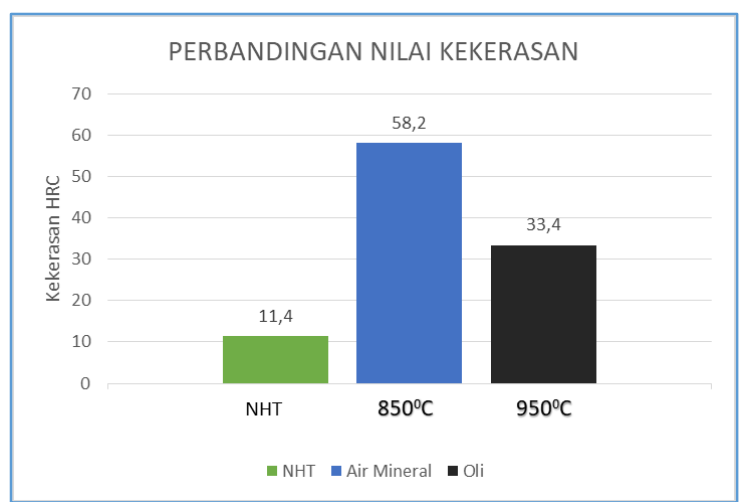

Gambar 11. Perbandingan media pendingin terhadap nilai kekerasan

Dari grafik pada gambar 11 menunjukkan nilai kekerasan tertinggi pada baja AISI 1045 yang telah diberikan heat treatment kemudain di-quenching menggunakan air mineral berada di temperatur $850^{\circ} \mathrm{C}$ mengalami kenaikan yang sangat signifikan yaitu sekitar $510 \%$ yang awalnya 11,4 HRC menjadi 58,2 HRC. Sedangkan pada media quenching oli nilai kekerasan tertinggi berada pada temperatur $950^{\circ} \mathrm{C}$ yaitu yang awalnya 11,4 HRC menjadi 33,4 HRC atau naik sekitar 290\%. Media pendingin air cenderung menghasilkan nilai kekerasan yang lebih dibandingkan dengan media pendingin oli ini dikarenakan air dapat dengan mudah menyerap panas yang dilewatinya dan panas yang terserap akan cepat menjadi dingin. Karena laju pendinginan yang begitu cepat, maka atom tersebut terperangkap dalam larutan sehingga membentuk struktur martensite [3].

\section{Uji korosi}

Uji korosi ini dilakukan untuk mengetahui pengaruh temperatur dan media pendingin saat proses heat treatment terhadap seberapa besar korosi yang terjadi. Metode yang digunakan adalah dengan merendam material pada cairan $\mathrm{H}_{2} \mathrm{SO}_{4}$ 
selama 22 jam. Sedangkan untuk perhitungan korosi menggunakan metode kehilangan berat.

Data spesimen setelah dilakukan pengujian korosi pada baja AISI 1045 yang telah mengalami uji korosi didapatkan nilai laju korosi pada raw material/material tanpa heat treatment laju korosi rataratanya adalah 3,238 ipy. Data ini diambil sebagai bahan perbandingan laju korosi pada material yang telah diberikan heat treatment.

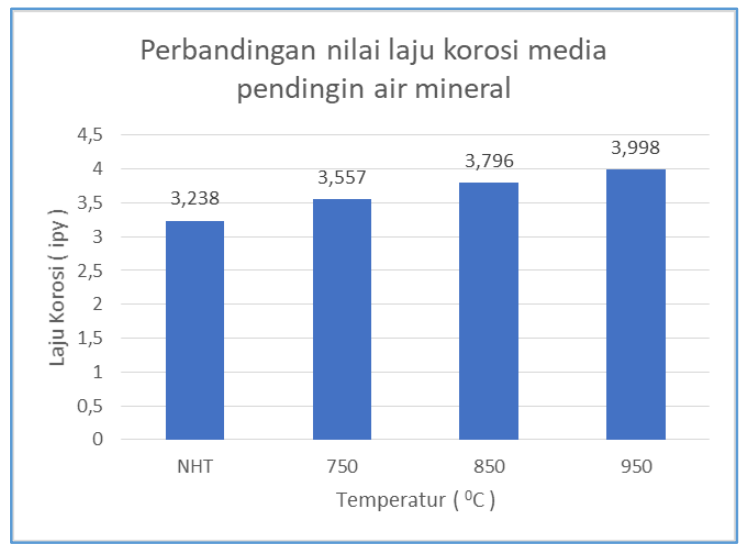

Gambar 12. Laju korosi media pendingin air mineral

Dari garafik menunjukkan semakin tinggi temperatur yang diberikan pada saat proses heat treatment semakin tinggi pula laju korosi yang terjadi, dimana pada material non heat treatment laju korosinya sebesar 3,238 ipy, temperatur $750^{\circ} \mathrm{C}$ sebesar 3,557 ipy, temperatur $850^{\circ} \mathrm{C}$ sebesar 3,796 ipy, dan temperatur $950^{\circ} \mathrm{C}$ sebesar 3,998 ipy akan tetapi kenaikan laju korosi tidak terlalu signifikan.

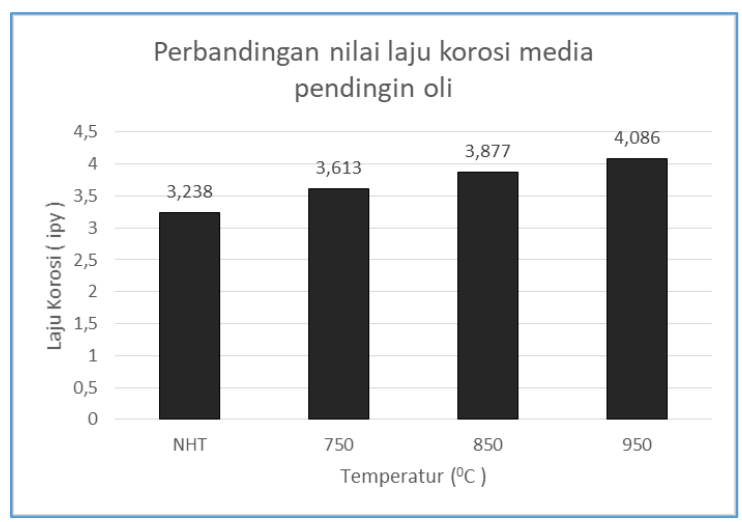

Gambar 13. Laju korosi media pendingin oli
Dari grafik menunjukkan peningkatan laju korosi, dimana pada material non heat treatment laju korosinya sebesar 3,238 ipy, temperatur $750^{\circ} \mathrm{C}$ sebesar 3,613 ipy, $850^{\circ} \mathrm{C}$ sebesar 3,877, dan pada temperatur $950^{\circ} \mathrm{C}$ laju korosinya sebesar 4,086. Semakin tinggi temperatur yang diberikan saat proses heat treatment maka berbanding lurus dengan laju korosi yang semakin meningkat juga.

\section{Perbandingan nilai laju korosi media pendingin air mineral dan oli}

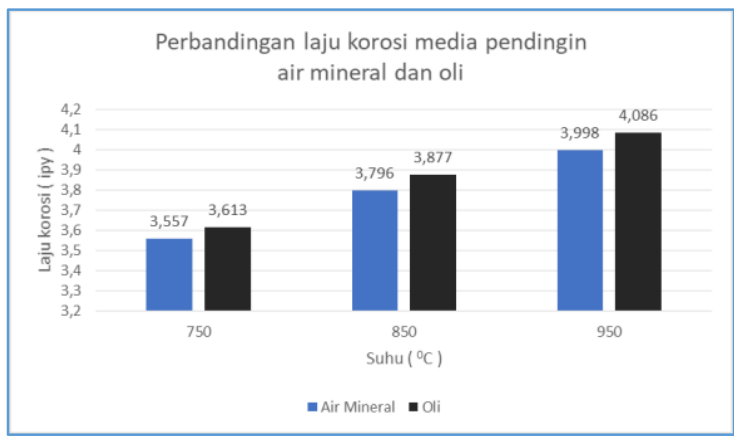

Gambar 14. Perbandingan laju korosi media pendingin air mineral dan oli.

Pada grafik menunjukkan media pendingin oli mempunyai laju korosi yang lebih tinggi daripada air mineral pada temperatur $750^{\circ} \mathrm{C}, \quad 850^{\circ} \mathrm{C}$, mapun temperatur $950^{\circ} \mathrm{C}$. Diama laju korosi tertinggi air mineral adalah 3,998 ipy terjadi pada temperatur quenching $950^{\circ} \mathrm{C}$ dan 4,086 ipy untuk air terjadi pada temperatur quenching $950^{\circ} \mathrm{C}$. Ini dikarenakan oli bisa menghasilkan zat pengotor di permukaan logam pada saat oli tersebut terbakar ketika proses quenching menyebabkan terjadinya reaksi reduksi tambahan sehingga lebih banyak atom logam yang teroksidasi.

\section{Pengaruh nilai kekerasan terhadap} laju korosi media pendingin air mineral

Material yang didinginkan dengan air mineral mengalami kenaikan nilai kekerasan dan laju korosi yang bervariatif dimana laju korosi meningkat sampai dengan nilai kekerasan 51,7 HRC dengan nilai lju korosi 3.998 ipy tetapi mengalami penurunan laju korosi dinilai kekerasan 58,2 HRC sebesar 3,796 ipy. Ini 
diakibatkan pengaruh temperatur quenching pada saat proses heat treatment (Gambar 15).

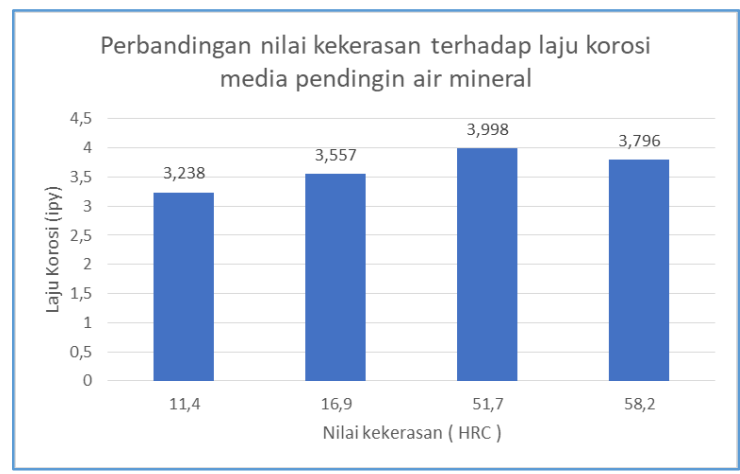

Gambar 15. Perbandingan nilai kekerasan terhadap laju korosi

\section{Pengaruh nilai kekerasan terhadap laju korosi media pendingin oli}

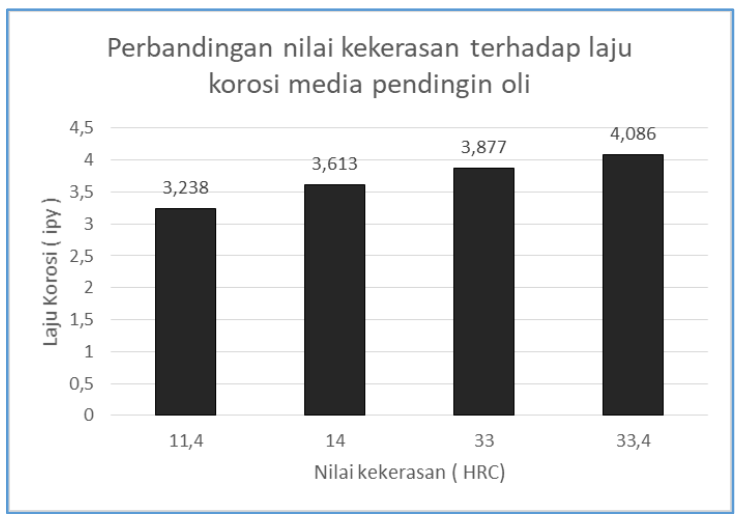

Gambar 16. Pengaruh nilai kekerasan terhadap laju korosi

Pada grafik menunjukkan laju korosi pada media quenching oli mengalami kenaikan yang sebanding lurus dengan nilai kekerasan. Dimana semakin keras material semakin tinggi juga laju korosi yang terjadi. Laju korosi terendah adalah 3,613 ipy pada nilai kekerasan 14 HRC dan 4,086 ipy pada nilai kekerasan 33,4 HRC.

\section{Perbandingan pengaruh nilai kekerasan terhadap laju korosi}

Nilai kekerasan pada matreial non treatmen yaitu dengan nilai kekerasan 11,4 HRC dengan nilai laju korosi sebesar 3,238 ipy (Gambar 17). Pada titik kedua nilai kekerasan media pendingin air mineral adalah 16,9 HRC dengan laju korosi 3,557 ipy, dan media pendingin oli $14 \mathrm{HRC}$ untuk nilai kekerasan dan 3,613 ipy untuk laju korosinya.

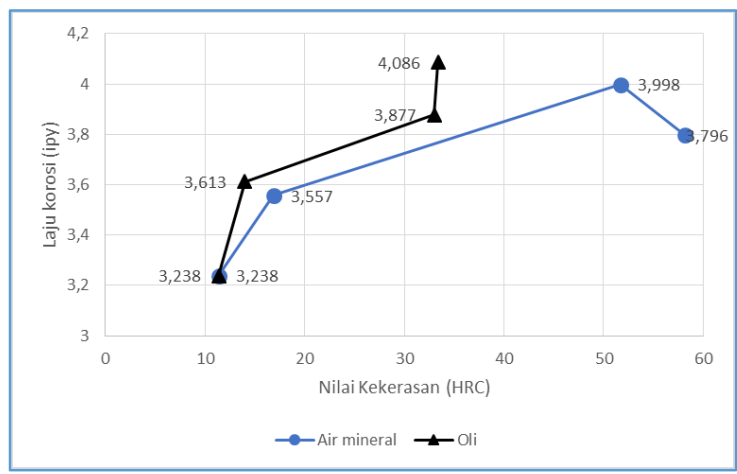

Gambar 17. Perbandingan pengaruh nilai kekerasan terhadap laju korosi

Titik ketiga nilai kekerasan media pendingin air mineral adalah 51,7 HRC dengan laju korosi 3,998 ipy, dan media pendingin oli 33 HRC untuk nilai kekerasan, dan 3,877 ipy. Titik keempat nilai kekerasan media pendingin air mineral adalah 58,2 HRC dengan laju korosi 3,796 ipy, dan media pendingin oli 33,4 HRC untuk nilai kekerasan, dan 4,086 ipy untuk laju korosinya. Jadi semakin keras material maka akan semakin cepat juga laju korosinya.

\section{Pembahasan}

Hardening merupakan heat treating yang tujuan utamanya adalah untuk mengeraskan baja. Besarnya kekerasan yang diperoleh dari proses hardening dipengaruhi oleh kandungan karbon, unsur paduan, dan jenis media pendingin yang digunakan. Pada penelitian ini, dengan menggunakan spesimen baja AISI 1045 peneliti mencoba untuk membandingkan penggunaan media pendingin dan temperatur yang berbeda pada proses hardening pada baja AISI 1045 terhadap laju korosi. Dari analisa statistik pada data hasil penelitian dapat diketahui bahwa perbedaan jenis media pendingin dan temperatur yang digunakan pada proses hardening pada baja AISI 1045 mempunyai pengaruh yang nyata terhadap kekerasan dan laju korosi. Dalam penelitian ini proses hardening baja AISI 1045 dilakukan dengan temperatur dan media pendingin yang berbeda. Dimana temperatur saat 
proses quenching dan media pendingin yang digunakan sangat berpengaruh terhadap nilai kekerasan yang didapatkan. Pada proses quenching air mineral pada temperatur $750^{\circ} \mathrm{C}$ didapatkan nilai kekerasanya adalah 16,9 HRC sedangkan media pendingin oli sebesar 14 HRC. Pada temperatur $850^{\circ} \mathrm{C}$ nilai kekerasan media pendingin air mineral adalah 58,2 $\mathrm{HRC}$ dimana nilai kekerasan meningkat lebih dari 5 kali lipat sedangkan media pendingin oli nilai kekerasan yang didapatkan adalah $33 \mathrm{HRC}$, dan pada temperatur $950^{\circ} \mathrm{C}$ nilai kekerasan media pendingin air mineral adalah 51,7 HRC sedangkan media pendingin oli 33,4 HRC. Nilai kekerasan media pendingin air lebih tinggi di semua temperatur quenching dibandingkan dengan media oli, dikarenakan air dapat dengan mudah menyerap panas yang dilewatinya dan panas yang terserap akan cepat menjadi dingin. Karena laju pendinginan yang bgitu cepat, maka atom tersebut terperangkap dalam larutan sehingga membentuk struktur martensite.

Temperatur pada saat quenching sangat perpengaruh terhadap laju korosi pada material. Dimana semakin tinggi temperatur yang diberikan saat Heat treatment maka akan semakin besar pula laju korosi yang terjadi. Itu dikarenakan salah satu penyebab korosi adalah saat proses heat treatment dan pengaruh temperatur. Laju korosi pada material baja AISI 1045 dengan media pendingin air mineral dan panas yang diberikan $750^{\circ} \mathrm{C}$ adalah 3,557 ipy. Kemudian meningkat di temperatur $850^{\circ} \mathrm{C}$ dengan laju korosi 3,796 ipy dan semakin meningkat di temperatur $950^{\circ}$ dengan 3,998 ipy. sedangkan untuk media pendingin oli pada temperatur $750^{\circ} \mathrm{C}$ laju korosinya adalah 3,613 ipy. Dan pada temperatur $850^{\circ} \mathrm{C}$ laju korosinya 3,877 ipy sedangkan pada temperatur $950^{\circ} \mathrm{C}$ adalah 4,086 ipy.

Dari hasil penelitian didapatkan nilai kekerasan juga berpengaruh terhadap laju korosi, dimana semakin keras material maka laju korosinya juga semakin tinggi itu diakarenakan adanya tegangan sisa yang dihasilkan saat proses pembentukan fasa martensite. Perbedaan temperatur dan laju pendinginan tidak hanya menghasilkan struktur mikro yang variatif, tetapi juga menghasilkan tegangan sisa yang dapat mengakibatkan baja menjadi sangat sensitif terhadap terbentuknya retak, baik retak selama proses manufaktur maupun pemakaian yang mengakibatkan terbentuknya korosi.

\section{Kesimpulan}

Temperatur dan media pendingin saat proses heat treatment sangat berpengaruh terhadap nilai kekerasan yang dihasilkan pada baja AISI 1045. Dimana untuk media pendingin air kekerasan maksimal yang dihasilkan yaitu pada temperatur quenching $850^{\circ} \mathrm{C}$ dengan nilai 58,2 HRC dan media pendingin oli pada temperatur $950^{\circ} \mathrm{C}$ dengan nilai kekerasan 33,4 HRC. Dimana semuanya naik signifikan dibandingkan raw material sebesar 11,4 HRC.

Temperatur dan media pendingin juga memepengaruhi laju korosi yang terjadi pada baja AISI 1045. Dimana semakin tinggi temperatur pada saat proses quenching semakin tinggi pula laju korosinya, dimana laju korosi tertinggi yaitu terjadi pada material yang diquenching pada temperatur $950^{\circ} \mathrm{C}$ dengan laju korosi 4,086 ipy lebih tinggi dibandingkan material yang di-quenching dengan air yaitu sebesar 3,988 ipy pada temperatur $850^{\circ} \mathrm{C}$.

\section{Referensi}

[1]. Gunawan, Eddy. 2017. Pengaruh Temperatur Pada Proses Perlakuan Panas Baja Tahan Karat Martensitik AISI 431 Terhadap Laju Korosi Dan Struktur Mikro. Engineering and sains journal. 1. (55-66)

[2]. Bahtiar, M. Iqbal, Supramono. 2014. Pengaruh Media Pendingin Minyak Pelumas SAE 40 Pada Proses Quenching dan 
Tempering Terhadap

Ketangguhan Baja Karbon

Rendah. Jurnal Mekanikal 5(1):455-463

[3]. Cinantar, Jeffri. 2107. Pengaruh Quenching, Austempering, Dan Quenchtempering Terhadap Kekerasan Dan Struktur Mikro Pada Besi Cor Kelabu. UM Metro

[4]. Budiyanto, E., \& Yuono, L. D. (2018).

Peranan Aerasi Sel Elektrolisis Dalam Pembentukan Pori pada Proses Anodizing Logam Aluminium. Turbo: Jurnal Program Studi Teknik Mesin, 7(2).

[5]. Perdana, Dony. 2017. Pengaruh Variasi Temperatur Pada Proses Perlakuan Panas Baja AISI 304 Terhadap Laju Korosi. Engineering and sain journal. 1. (67-72)

[6]. ASM. (1991). ASM metals handbook Vol. 4: Heat treating. New York: ASM Handbook Committee.

[7]. Firmansyah, A. A. 2014. Analisa Struktur Mikro dan Kekerasan Baja S45C Pada Proses Quench-Temper dengan Media Pendingin Air. JTM 3(1): 113 119 